\title{
MAINSTREAMING CORRUPTION POVERTY AND DEVELOPMENT IN NIGERIA
}

\author{
Jolaade Omede ${ }^{1}$ \\ Arinze $\mathrm{Ngwube}^{2}$
}

\section{Introduction}

The culture of corruption has continued to plague the Nigeria society in all sectors at an alarming rate creating culture of acceptability of such a way of life. That corruption is endemic and has assumed a national way of life is a disturbing reality in Nigeria. It is this light that Achebe (I983, 38 ) avers that anyone who can say that corruption in Nigeria has not yet reached an alarming proportion is either a fool, crook or else does not live in Nigeria. He further posits that the situation has become so worse to the extent that keeping a Nigeria from being corrupt is like preventing a goat from eating yam. Corroborating this view, Anazodo, Okoye and Ezenwile (2OI2, I24) submit that corruption in Nigeria has affected all the political, economic and social facets of Nigeria and these are responsible for decayed infrastructure,downturn of the economy, fragile political institutions and steady decline in all institutions of national development.

However corruption is a universal phenomenon, the rate and toleration of corruption acts vary from place to place, basically determined by the socio-cultural environment in a particular place. In Nigeria, corruption has become strange than a fairy tale increasing and manifesting in unimaginable magnitude is raging between and within communities, gradually assuming the character of the society. It has to be tolerated and encourage by the agents of socialisation (the family, the school, the church/ mosque, peer groups, media, occupational groups, etc) which ordinarily should have been responsible for disapproving acts that are anti-social, anti-

I Department of Political Science, University of Ilorin, Ilorin, Nigeria. E-mail: medajol@ yahoo.com.

2 General Studies Unit, Federal University Oye-Ekiti, Oye, Nigeria. E-mail: ngwube@ hotmail.co.uk. 
people and anti-development. The continuing manifestation of corruption and the seeming helplessness of the state to curb the menace clearly indicate that the Nigerian state has not just failed to uphold its traditional moral values, its religious norms and tenets but has rather encouraged raw, distorted, unbridled and unregulated capitalist tendencies. This can be seen in the habits of excessive materialism and the inordinate and excessive accumulation of national wealth by individuals without regard to the collective interest and welfare of the larger society (Irikana, Epelle and Awortu 2013, 30).

In other words, obsession with materialism, compulsion for a shortcut to affluence, glorification and approbation of ill-gotten wealth by the general public are among the reasons for the persistent corruption and indiscipline in Nigeria. It is important to reiterate that corruption is a universal phenomenon and its roots are to be traced within the society and not in human psychology (Irakana, Epelle and Awortu 2013, 34). What is the impact of the emerging socio-economic and political culture on the development agenda of the Nigerian state? This paper is divided into six sections Theoretical framework, Conceptional clarification, the interface between corruption, poverty and development in Nigeria, conclusion.

\section{Theoretical Framework}

\section{Anomie Theory}

The relationship between social class and crime in Nigeria is an issue that continues to attract attention from the media, policy makers and law enforcement agencies. The perpetrators of crime are economically disadvantaged and poor. Merton (1957) applied the concept of anomie to explain the causes of crime in a society. The word anomie, according Durkheim is used to describe a social context in which the moral order has broken down for an individual or group, a situation in which social structural constraints of behaviour become inoperative. According to Durkheim (1938) an anomie society is one in which rules of behaviour (norms) have broken down or become inoperative during the period of rapid social change or social crisis such as war or famine. An anomic society is not able to control human aspirations and demands. Anomie is most likely to occur in societies that are moving from mechanical to organic solidarity. Merton (I957) applied the ideas of Durkheim to criminology in his theory of anomie. Merton used a modified version of the concept of anomie to fit social, economic and cultural conditions found in modern U.S. society. He found that the two elements of culture interact to produce potentially 
anomic conditions, culturally defined goals and socially approved means for obtaining them. For example, the United States society-stress the goals of acquiring wealth, success and power. Socially permissible means include hard work, education and thrift. The illegitimate means are force and fraud because the social structure effectively limits the availability of legitimate institutionalized means; a strain is placed on people. Merton believed that strain could affect people in social classes but he acknowledged that it would most likely affect members of the lower class. Merton (1957) argued that this feeling of norm-less arises when an individual is expected to achieve certain universal goals but does not have access to the appropriate means for achieving them. He considered materials wealth a universal goal to which all aspire and the appropriate means of achieving wealth include securing a good education and securing a good job. When individuals do not have access to good education and jobs, Merton predicted that they might be tempted to obtain material wealth through inappropriate means such as criminal activity. Such individuals, not surprisingly, would more likely come from the lower classes (Giddies \& Duncier 2000).

The anomie theory see corruption (deviant behaviour) as emanating from the social structure of the society which exerts a definite pressure upon certain individuals in the society to engage in non -conforming conduct. Merton (I960) has succinctly put this in another way when he asserts that a society in which there is an exceptionally strong emphasis upon specific goals without a corresponding institutional means will lead to anomie. Metiboba (2012, I59) notes each culture establishes goals and interests which people are encouraged and expected to pursue and prescribes the method to be followed in seeking these approved objectives. It is when these means fail to match the goal of the individual in question that the individual becomes socially disorganized. The theory is useful because it has explained the cause of different forms of deviant behaviour.

However the Nigerian society tends to over emphasize the individual goal of attainment at the expense of the legitimate means of achieving these set goals. In Nigeria material acquisition has virtually become the ultimate set goals and the society does not appear to be concerned with how one "makes it" or has come to "belong". All that is important is that one has "arrived". The marked discrepancy between the goals and means in the society invariably leading to various forms of corruption such as embezzlement and diversion of public funds; offering and acceptance of bribe, electoral fraud, recklessness and impunity, examination malpractice, which in all mar development efforts in Nigeria.

\section{Conceptualising Poverty, Corruption and Development}


Poverty according to Aliyu $(2003,2)$ is a situation where an individual or group people can be said to have access to his/their basic needs, but is comparatively poor among persons or the generality of the community .It means that the standard of living as obtained within an individual's environment determines if that individual is considered poor or not. It is a basic fact that what is considered a poverty level in on e country or community may well be the height of well being in another (European Commission 2004). Despite these various definitions of poverty that makes it difficult to arrive at clear consensus on what the concept means, there are 'compromise' definition of poverty generally recognized and used by different people. One of such is that of the Central Bank of Nigeria (I999, I) which views poverty as a state where an individual is not able to cater adequately for his or her basic needs of food, clothing and shelter; is unable to meet social and economic obligations; lacks gainful employment, skills, assets and self -esteem; and has limited access to social and economic infrastructure such as education, health, portable water and sanitation. In other words, poverty is the lack of multiple resources that leads to hunger and physical deprivation.

Any endeavour to conceptualize corruption may seem almost a mere rehash of existing conceptions of the phenomenon. Rehashing old definitions would seem easy. Conceptualizing corruption is not an easy task. Indeed, it is a daunting and challenging venture. (Olugbenga 2007; Odofin and Omojuwa 2007; Ajibewa 2006; Faloore 2010; Igbuzor 2008). According to Andrig and Fjeldstad (2OOI, 4) "corruption is a complex and multifaceted phenomenon with multiple causes and effects, as it takes on various forms and functions in different contexts". In fact, one of the major crises in conceptualizing corruption is that while it is difficult for it to disappear it has a capacity to take on new forms (Andrig and Fjelstad 200I; Girling 1997). The difficulty of defining corruption is first a function of its being a secret and clandestine activity and secondly because it has many manifestations, dimensions and forms. That is why Johnston argues that studying corruption is a tricky business. According to him:

Definitions are controversial, and solid evidence is often elusive. Descriptive accounts may be clouded by self serving equivocations. Equally subtle is the question of the significance of a corrupt act - not only its consequences, but also its meaning as perceived by citizens and officials alike (in Ogundiya 2009: 282). Be that as it may Tanzi has argued that while it may not be easy to define corruption, the crisis associated with corruption is not difficult to recognize (Tanzi I998). The word corruption is originally from the Latin verb rumpere which means to break (Abdul-Ismail n.d.). Following from the above, corruption means the breaking of a certain code 
of conduct for the personal benefit of the perpetrator.

Many definitions of corruption have been put forward. For example, Sen defines it as the violation of established rules for personal gain and profit (in Aluko 2009, 2). Osoba defines it as "an anti-social behaviour conferring improper benefits contrary to legal and moral norms, and which undermines the capacity of authorities to improve the living conditions of the people" (in Aluko 2009, 3) The World Bank defines corruption as: The abuse of public office for private gains. Public office is abused for private gain when an official accepts, solicits, or extorts a bribe. It is also abused when private agents actively offer bribes to circumvent public policies and processes for competitive advantages or profit. Public office can also be abused for personal benefit even if no bribery occurs, through patronage and nepotism, the theft of state assets, or the diversion of state resources (in Agbu 2003, 3). In J.S. Nye's classical definition, corruption is "behaviour that deviates from the formal duties of a public role (elective or appointive) because of private regarding (personal, close family, private clique) wealth or status gains" (Nye 1967,416 ). What we can deduce from the definitions above is that corruption entails any behaviour that deviates from accepted norm especially in the public space. It is any behaviour that goes against established rules, regulations, and established procedure. In short, corruption is behaviour that breaks the law or aid and abets breaking the law. Such behaviour usually confers undue and/or unmerited advantages on the perpetrator. Such behaviour also expresses the notion of a betrayal of trust especially in a democracy where public office is held in trust for the people.

Corruption has various forms and dimensions. Aluko has identified nine forms namely:

- Political corruption (grand)

- Bureaucratic corruption (petty)

- Electoral corruption

- Bribery

- Fraud

- Embezzlement

- Favouritism

- Nepotism (Aluko 2009, 5)

Other categorizations which do not differ from that of Aluko exist (see Yaru 2010; Adenugba 2009; Omotola 2006; Orngu 2006; Aghemelo and Oarhe 2003). What is important, however, is that in whatever form 
it manifests, corruption perverts public interest and unlawfully elevates private gain and advantage.

\section{Development}

The Indian economist and philosopher, Professor Amartya Sen makes the important point that democratic value, as much as economic values are critical in an accurate conception of development. These keys in with the vision of the American Nobel Prize winner, Joseph Stieglitz who definitively affirms that words like openness, partnership, and participation, women empowerment, and environmental health carry in their innards, a theory of development, as well as evidence that can lead to more successful development efforts. Development has been viewed variously to mean economic growth; a reduction in poverty, unemployment, inequality and dependency; provision of basic needs; and as democracy and good governance (Umo 2007, 600). It is important to see development as a process that involves the progress of people in the society. In as much as people, live within some form of social framework consisting of social, economic and political structures, development involves progressive changes or transformations of these structures (Okpaga I999, 35).

Development includes the eradication of absolute poverty, malnutrition, illiteracy, disease and unemployment. It has moved from specific economic goals like employment, status gain, and housing, water supply to non-economic goals as adequate health, education, environmental sanitation facilities and granting of personal and individual freedoms. These are indicators of real development. In a nutshell, the current idea of development places emphasis on people as the objects of attention and has gone beyond normal growth in the volume of goods and commodities. This shows that development is a process of societal advancement where improvement in the well being of people are generated through strong partnerships between all sectors, corporate bodies and groups in societies.

\section{Effect of Corruption on Poverty and Development in Nigeria}

Various authors have written the innumerable negative impacts of corruption on the socio-political and economic development of societies (Enojo 20I2; Agaba 20I2; Sen I999). It has been noted that corruption causes a reduction in quality and quantity of goods and services available to the public, as companies would cut corners to increase profit margins. Corruption is a disease spreading itself throughout our polity and we need 
to inoculate our country against this infection. Corruption diverts resources from the poor to the rich; increases the cost of running businesses, distorts public expenditures, and deters foreign investment (Mauro I997; Wei I997 and Alesina 1999). Corruption saps a country's economy by hampering tax collection and undermining the enforcement of important regulation. Corruption also creates loss of tax revenues and monetary problems leading to adverse budgetary consequences (Murphy I993), and is likely to produce certain composition of capital flows that makes a country more vulnerable to shifts in international investors' sentiments and expectations (Lambsdorff 2000 and 2005). In addition corruption has an adverse effect on human development, and increases the cost of basic social services (Kaufman I998).Corruption has had severe negative consequences on economic growth and development of Nigeria. It packs our unemployed youths into stadia without proper consideration. It humiliates and kills our youths. Nigeria's Human Development index at 0.459 lags behind the sub Saharan Africa average of 0.463 and the world average of 0.682 . The inequity adjusted HDI is even further disappointing at 0.278 . The low point in the global scale is 0.456 . The Multi -Dimensional poverty index (MPI) shows that $54 . \mathrm{I} \%$ of the population live in poverty, with $57.3 \%$ in intense deprivation (HDI 20II). Over 70\% of Nigeria citizens live below the poverty line (International benchmark is \$I.5 per day), and Nigeria is ranked 156 th out of 187 countries in the world ranking of nations using the Human Development index (UNDP 20II). Meanwhile Nigeria has earned close to \$450 billion since I970 on oil receipts alone. Between May I999 and June 2008 alone, the country earned over $\$ 205$ billion (cited by Wokoma 2008). In Switzerland $7.4 \%$ of the population is below the poverty line.

Even where improper conduct, such as fraud and bribery, does not directly involve government, the public effects are severe. Corruption has adversely affected governance and the larger social structure. It has crippled the state's ability to deliver for its citizen's enjoyment of even the minimum social and economic rights, including health and education. This generally leads to a retardation of economic development and to the deterioration of whatever public infrastructure has been put in place. It has been observed that in Nigeria, unbridled corruption has led to bad governance. Corruption and mismanagement swallow about 40 percent of Nigeria's \$20 billion annual oil income (Ribadu 2004).Corruption disrupts the capital flow throughout entire developing nations. Tax income is generally far below what the government requires in order carrying out basic services in corrupt nations. When money is stolen, the police are not paid, salaries not commensurate with their task. Police are not paid regularly and are underpaid .The police spend their time hustling for tips instead of training 
and pursuit of criminals. The police never investigate cases, they never track criminals; and when they do arrest suspects they release them for some money. The Consequence of the money that could improve the security services being stolen is poverty of the police force and deaths of the people from cheap criminals who would not last a day on America streets. We lose people as a consequence of our tolerating a corrupt society.

Most Nigerians are treated with suspicion in most business dealings thereby making some honest Nigerians to suffer the stigma of corruption due to stereotyping. Ribadu (2006) opined corruption is worse than terrorism because it is responsible for perpetual collapse of Infrastructure and institutions in Nigeria. It is the cause of the endemic poverty and Underdevelopment. When people in government embezzle funds, They have to bribe many unworthy people in the process, it has to placate and please many co-conspirators. The consequence of this is that the society feels the presence of money in the hands of the unworthy. Money flows from one thieve to another crooked friend and then to terrorist's hands, guns are bought. Thugs are hired by the politicians and their friend's .Sometimes; terrorists are paid with these stolen funds. The Poverty is found to persist in Nigeria because of the mismanagement of resources and corruption, found particularly not only in the public sector (Ayua 2001). Corruption stifles businesses that are unwilling to engage in this nefarious activity; ironically, it also eventually destroys the companies that yield to this practice, thus halting or at least delaying considerably, the march toward economic progress and ultimately sustained development (Gire I999). Nigeria remains one of the most corrupt nations in the world, according to the latest report by Transparency International. In the group's Corruption Perceptions Index 2013, Nigeria ranked I44th, out of I77 nations in the world, scoring 25 points out of a possible Ioo points. Nigeria's corruption performance this year was worse than last year's, when it scored 27 points. This year, Nigeria shared the podium of infamy with crisis-torn Central African Republic and neighbour, Cameroon.

In a similar damning reported 2013 the then US Ambassador to Nigeria, Terence McCauley, reportedly told the Nigerian government to demonstrate more courage and conviction in its crusade against graft, insisting that it was the only way to "send a clear signal that the country is indeed committed to good governance, to the security of its citizens, and to its rightful place as a significant actor on the global stage." Unfortunately, corruption has been identified as the major reason for the arrested development in the country. It is responsible for reduced public spending, which results in huge infrastructure deficits, especially poor roads, lack of electricity, inadequately-equipped hospitals and low quality of education. It 
is also fingered in the pervasive insecurity in the country, low quality of governance and general poor standard of living. The US report alleges that, in Nigeria, "Massive, widespread and pervasive corruption affected all levels of government and the security forces." While alleging that judges were not left out of the massive corruption ring, the report accused the government of not implementing the law on corruption effectively, thus deliberately allowing "officials (to) frequently engage in corrupt practices with impunity.

As concisely captured by Nebo $(2010,29)$ contends that:

Poverty in this land is artcifical; unemployment too is a self-inflicted scourge...The level of widespread poverty, unemployment, high incidence of corruption and insecurity of life and property in Nigeria exist only because our leaders both at the Federal, State and Local Government levels either do not know what to do or are profiting and deriving some form of psychological pleasure watching Nigerians suffer or therefore are reluctant to do something.

It is striking that corruption breeds poverty, sickness, low life expectancy and unequal distribution of income and wealth. Corruption and underdevelopment go hand in hand. One is the cause and the reason for the existence of the other.

\section{Conclusion}

Corruption is an impediment to nationhood. The question one would ask is, must it continue forever? It is time for total moral cleansing. The challenge lies with both leadership and followership to address this dread monster. Can the present crop of leaders muster the political will in fighting the cankerworm called corruption? Can the president and his team, with a singular resolve, create the needed irreversible process aimed at correcting the rot afflicting our political and public life? Nigeria begs for solution. One expects that Nigerians return to the original noble values of integrity, love and honesty, this is the only the country can move beyond its present status in terms of growth and development.

Hope is very vital in life; we will surely continue to live in hope, even when we die in despair. Barrack Obama talks of the audacity of hope so it will not be out of place to say that there is hope of finding a way out of corruption for Nigeria. Here one must accept that corruption is a vice and to purge a vice, virtue is needed. Since moral depravity is what engenders corrupt practices, it follows therefore, that an elevated moral life will quell participation in corruption. A morally sanitized individual will be less vulnerable to the courtship of corrupt companies. One can borrow a word 
from Mohandas K. Ghandi, father of the Indian nation: "The things that will destroy us are: politics without principle; pleasure without conscience; wealth without work; knowledge without character; business without morality; science without humanity and worship without sacrifice.

\section{REFERENCES}

Acemoglu, D., \& Verdier, T. (I998). Property Rights, Corruption and the Allocation of Talent: A General equilibrium Approach, Economic Journal, Vol. ro8.

Achebe, C. I983. The Trouble with Nigeria. Enugu: Fourth Dimension Publishers.

Akai, N., Horiuchi, Y., \& Sakata, M. 2005. Short-run and Long-Run Effects of Corruption on Economic Growth: Evidence from State level Cross - Section data for the United States. Osaka: Osaka International University Press.

Akkihal, R., Smith, H., \& Adkins, R. I997. "The Economics of Corruption in Developing Countries". The Coastal Business Journal Volume I, No I

Aliyu, S.U.R. 2007. Democracy, Corruption and Economic Development: Evidence from Nigeria, being a paper presented at that Nigerian Political Science Conference held at the Centre for Democratic Research and Documentation, Bayero University, Kano.

Aliyu, A. 2003. Re-Structuring of the Poverty Alleviation Activities of the Federal Government of Nigeria. Abuja: National Poverty Eradication Programme.

Amundsen, I. 2000. Corruption: Definitions and Concepts. Norway: Norwegian Agency for Development Cooperation (NORAD), Michelson Institute (CMI)

Anazado.R.Okoye, J.C and Ezenwille, U. 20I2. "Leadership Corruption: The Bane of Nigerian Development". African journal of Social Sciences, Vol2 (3).

Anoruo, E, and Braha, H. 2004. Corruption and Economic Growth: The African Experience. Retrieved June I4. http://www.jsd_africa.com /jsda/ spring2005/ articlepdf/arc_corruption\%20 and \% 20 economic\%2ogrowth.pdf

Barro, R. I990. "Economic Growth in a Cross - Section of Countries". Quarterly Journal of Economics Vol 106, No 2, p. 407 - 443.

Central Bank of Nigeria. I999. Nigeria Development Prospects .Poverty Assess- 
ment and Alleviation Study. Central Bank of Nigeria in Collaboration with the World Bank.

European Commission. 2009. Food Security: Understanding and Meeting the Challenges of Poverty. Luxembourg: Publication office of the European Union.

Engle, R.F. and Granger, C.W.J. 1987. "Cointegration and Error Correction: Representation, Estimation, and Testing”. Econometrica, SS; 25I 276. I7

G.T., \& Davoodi, H.R. 2002. Corruption, Structural Reforms and Economic Performance in the Transition Economies. Washington DC: International Monetary Fund.

Gire, J.T. 200I. "A Psychological Analysis of Corruption in Nigeria". Online Publication. Granger, C.W.J. and Newbold, P. (I974). Spurious Regression in Econometrics. Journal of Econometrics Vol 2.

Gupta, S.H, Davoodi and Alonso Terme. 1998. "Does Corruption Affect Income inequality and poverty?" IMF working Paper 98/76. IMF, Washington D.C

HRW. 20II. Corruption on Trial? The Record of Nigeria's Economic and Financial Crimes Commission, August.

Huntington, S.P. I968. Political order in changing Societies. New Heaven: Yale University Press.

Irikana, G.J; Epelle, Awortu, B.E. 20I3. "Cultural Disorganisation and Deepening Crisis of corruption in Nigeria; A Discourse”. Review of Nigerian Politcal Economy vol2 Number I\&2January-December 2013.

Jones, L. and Manuelli, R. I990. A Convex Model of Equilibrium Growth: Theory and Policy Implications." Journal of Political Economy 98(5): I008-1038.

Kaufmann, D. I997. "Corruption: some myths and Facts: An early inversion" was published in foreign policy, summer I997 Pp. II4 - I3I.

Leff, N.H. I964. "Economic Development through Bureaucratic corruption”. The American Behavior Scientist, Vol. 8 (2): 8 - I4.

Lucas, R. E. I988. "On the mechanics of Economic Development". Journal of Monetary Economics.

Lui, F.T. I985. "An equilibrium Queuing model of Bribery" Journal of Political Economy.

Mauro, P. I997. The Effects of Corruption on Growth, Investment and Government Expenditure: A cross country analysis. Washington DC: Institute for International Economics. 
Mauro, P. I995. "Corruption and Growth". Quarterly Journal of Economic, Vol. IIO, No 3 .

Mo, P.H. 200I. "Corruption and Economic Growth" journal of Comparative Economic, Vol. 29, No 66 p. 7-9.

Nebo, C.O. 20Io. Nigerian Sectoral Underdevelopment and Leadership Challenges. The Igbo Perspective. Ahajioku Lecture.

Okpaga, A. I999. "The Post-Colonial State in Africa and the Prospects for Development and Democracy". Journal of Political and Administrative Studies, Voli (I).

Pellegrini, L and Gerlagh, R. 2004. "Corruption's Effect on Growth and its Transmission Channels", Kylos, 57: I8 429 - 56.

Rahman, A, Gregory, K. and Kapil, K. I999. "The effects of corruption implications for Bangladesh". Policy Research working Papers, WPS2479, World Bank, Washington D.C.

Ram, R. 1986. "Government Size and Economic Growth: A New Framework and Some Evidence from Cross-Section and Time -Series Data." American Economic Review. Vol 76: I9I-203.

Rebelo, S. I99I. "Long run Policy Analysis and Long run Growth". NBER Working Paper No 3325.

Rock, M.T and Bonnett, H. 2004. "The Comparative Politics of Corruption: Accounting for the East Asian Paradox in Empirical studies of Corruption, growth and investment”. World Development: Vol. 32: 999 - IOI7.

Romer, P. I986. “Increasing Returns and Long Run Growth.” Journal of Political Economy, vol. 94, No. 2, I002-I037.

Rose-Ackerman, S. I997. Corruption and Government: Causes, consequences and Reform. Cambridge: Cambridge University Press.

Solow, R. 1956. "A Contribution to the Theory of Economic Growth." Quarterly Journal of Economics 70:65-94.

State Department. 2013. "Nigeria," Country Report on Human Rights Practices 20I2, April.

Summers. 1977. Speech to the Summit of Eight Denner.

Swan, T. 1956. "Economic Growth and Capital Accumulation." Economic Record 32:334-36r.

Tanzi, V. and Davoodi. I997. "Corruption, public investment and growth", IMF Working Paper, WP97/I39.

The country's U.N. 20I2. "Conference on Trade and Development (UNCTAD)", World Investment Report 2012, May 7. 
Todaro, M.P. 2003. Economic Development. Singapore: Pearson Education Ltd.

Umo, J.U. 2007. Economics: An Africa Perspective. 2nd Edition Lagos: Millennium Text Publishers.

UNDP. 20II. Human Development Report.

UNDP. I997. “Corruption and Good Governance United Nations Development Programme Discussion" paper 3.

United Nations. 200I. "UN Global Programme against Corruption. Anti-Corruption toolkit”. www.odcep.org/pdf/crime/toolkit/fitof7.pdf I9

Voskanyan, F. 2000. A study of the Effects of Corruption on Economic and Political Development of Armenia. A published M. Sc. Thesis of the Graduate School of Political Science and International Affairs November 2000 .

Wei, S. J. I997. Corruption in Economic Development. Beneficial Grease, Minor Annoyance, or major obstacle? Harvard University and the National Bureau of Economic Research, Working Paper, the World Bank.

World Bank. I997. Helping Countries combat corruption: The Role of the World Bank. Washington DC: World Bank.

World Bank. 2000. The Anti Corruption in Transition: A Contribution to the Policy Debate. Washington DC: World Bank. 


\section{ABSTRACT}

The paper gives an outline of Nigeria's experience on corruption in the context of poverty and Development. It discusses the effects of corruption which are rooted in the political and economic situation of the polity. The challenge of corruption is at the root of our underdevelopment .It has become so pervasive that many essential public projects for which vast sums of money have been paid to concerned contractors have been abandoned. And when such public projects have been completed, their costs are always higher in comparison with the costs of similar projects in other countries. In Nigeria corruption stifle economic growth, reduce economic efficiency and development despite the enormous resources in the country. It depends essentially on data from secondary sources such as books, journal articles, government publications, among other relevant documents. The data were analyzed qualitatively using the descriptive analytical method in order to achieve the primary objective of the paper.

\section{KEYWORDS}

Corruption; Poverty; Development; Nigeria.

Received on May 26, 2017. Approved on January 8, 2017. 